\title{
A Case Study of Value-Added Tax Issues on Customer Loyalty Programs in Korea
}

\author{
Namryoung Lee ${ }^{1}$ \\ ${ }^{1}$ Korea Aerospace University, Korea \\ Correspondence: Namryoung Lee, Korea Aerospace University, 200-1, Hwajeon-dong, Deokyang-gu, \\ Goyang-city, Gyeonggi-do, 412-791, Korea. Tel: 822-300-0093. E-mail: nrlee@kau.ac.kr
}

Received: February 24, 2014

Accepted: March 21, 2014

Online Published: May 25, 2014

doi:10.5539/ijef.v6n6p152

URL: http://dx.doi.org/10.5539/ijef.v6n6p152

\begin{abstract}
This research examines the issue of taxation on customer loyalty programs (so called "mileage programs"). We refer to a case in business practice in order to closely observe the appropriateness of the current taxation system. The Company addressed (hereafter "Company") maintains both tax-exempt and taxable operations. The controversy arises when the points earned in the tax-exempt business are exchanged for services, provided by the taxable operations. While it is frequently argued that the transactions of such nature should be taxed, we conclude that they are not liable for taxation based on the related laws and regulations. Offers for free service in discussion contravenes the legally defined range of service provided and what's more, the points earned do not carry monetary value. Furthermore, the current value-added tax laws confine property liable for taxation to goods under the article No. 48. Also, the revenue from service made by mileage (the points) should be excluded from the tax base according to the reinterpretation of the Ministry of Strategy and Finance Case No. 319 (March $29,2006)$ However, here arises the controversy. When points are utilized as a means of payments, they are expected to be subject to taxation. The same logic is to be implemented in the light of tax equality. Meanwhile, once value-added tax is imposed on the revenue made by mileage (the points), it would largely impact the industry offering loyalty programs to its customers. Thus, it is necessary to establish tax laws and regulations concerning customer loyalty programs.
\end{abstract}

Keywords: customer loyalty programs, mileage, the free service, monetary value, fairness of taxation

\section{Introduction}

Korea has adopted International Financial Reporting Standards (hereafter, K-IFRS) for all listed companies and some unlisted companies since 2011. K-IFRS puts emphasis on principles rather than specific rules, consolidated financial statements rather than individual financial statements and fair value measurement of their assets and liabilities at the fair value. As different accounting treatments from Korean GAAP (Generally Accepted Accounting Principle) is giving a great impact on common current practice, both the companies and auditors are facing difficulties in adapting to the new accounting standards. Among detailed requirements on various different transactions and events, K-IFRS users may need to make substantial changes to their accounting policy for customer loyalty programs. Customer loyalty programs have grown more widespread in recent years. Including, retailers, credit card companies, airlines and hotels, various types of product and service businesses grant award credits as incentives to customers.

Under new accounting standards for customer loyalty programs, K-IFRS 2113, the consideration allocated to the award credits should be classified as "deferred revenue" in the entity's financial statements. Different accounting treatments between K-IFRS and Korean GAAP could have a material impact on companies' income and/or financial ratios. Airline industry showed a decrease in shareholder's equity and an increase of debt to equity ratio. In Korean Airlines, for the first year of K-IFRS adoption, debt to equity ratio has increased to $825 \%$, a $233.7 \%$ increase compared to the previous year as revenue that corresponds to mileages is deferred and classified as liabilities until mileage is used.

However, the provision of levying tax was newly established in the tax law revision in February 2010 in regards with mileage or point for the case of including the mileage equivalent amount in the tax base of value-added tax for the concerned fiscal year when receiving goods and paying by the accumulated mileage. Nonetheless, there has been no clear criterion for interpretation and it relies heavily on the established rules. In particular, the tax 
base for value added tax as to the free supply of services through mileage or point is more ambiguous. As pointed out by Chang (2011), the current systems and regulations related to the taxation of value added tax as to mileage are insufficient and a detailed regulation for this would be required. Based on the existing established rules, the value added tax for air-flight mileage is not being paid since it is regarded as a free provision of services. However, there also exists an argument that the value added tax for air-flight mileage should be paid from the perspective that air-flight mileage has monetary values or the perspective of tax equality. But when the value added tax for any transaction using mileage is levied, it will likely cause a huge impact on those industries including the airline industry, which are actively utilizing mileage program as a sales promotion tool. And this may consequently create a result that doubles the burden to the relevant companies in addition to the concerns associated with the financial accounting aspect with the change of accounting rule for mileage due to the implementation of International Financial Reporting Standards. In the current situation where the number of companies that aim to leverage the mileage system as a tool to create long-term profits by raising the loyalty of their customers is on the rise, it would be required to define the mileage related value added tax.

Hence, this research examines the issue of taxation on customer loyalty programs exemplifying a company which maintains both tax-exempt and taxable operations. Taxation for the transactions when the points earned in the tax-exempt business are exchanged for services may be discussed. The same logic is to be implemented in the light of tax equality. Based on the conclusion, we also suggest an impact on the related industries whole. The rest of this paper is organized as follows: Section 2 provides an examination of accounting standards and related tax law. Section 3 examines the issue of taxation on customer loyalty programs by referring a case in business practice and Section 4 concludes.

\section{Accounting for Customer Loyalty Programs and Value-Added Tax Act}

\subsection{Customer Loyalty Programs}

Customer loyalty programs are defined as programs that companies give award credits as incentives to their customers to purchase their products or services. Awards can be exchanged for goods or services supplied by the entity or a third party in the future. Established in 1981, American Airline's Frequent Flyer Program was the first airline loyalty program in the world.

Customer loyalty programs are widespread, being provided by various types of product and service businesses. Award credits are often named "points" or "mileage".

In accordance with behavioral loyalty research, revealed that mileage is effective to motivate next purchase, among many customer loyalty schemes, mileage is classified as explicit rewards directly support the value proposition of the product or service. Even though a loyalty's redemption rewards are delayed and less powerful, mileage is effective to motivate next purchase (Dowling \& Uncles, 1997).

While customer loyalty programs are being used as a strategy for the companies' competitive advantages, there is a paradox of customer loyalty programs. The Korea Fair Trade Commission (KFTC) proposes solutions. KFTC makes an effort to prevent customer damage in sectors including airlines mileage programs, by improving mileage expiration policy and increasing opportunities to use mileage.

\subsection{Accounting for Customer Loyalty Programs}

Customer loyalty programs are used by entities to provide customers with incentives to buy their goods or services. If a customer buys goods or services, the entity grants the customer award credits (often described as 'points'). The customer can redeem the award credits for awards such as free or discounted goods or services. The programs operate in a variety of ways. Customers may be required to accumulate a specified minimum number or value of award credits before they are able to redeem them. Award credits may be linked to individual purchases or groups of purchases, or to continued custom over a specified period. The entity may operate the customer loyalty program itself or participate in a program operated by a third party. The awards offered may include goods or services supplied by the entity itself and/or rights to claim goods or services from a third party.

Korean International Financial Reporting Standards 2113 clarifies accounting for customer loyalty programs as follows:

An entity shall account for award credits as a separately identifiable component of the sales transaction(s) in which they are granted (the 'initial sale'). The fair value of the consideration received or receivable in respect of the initial sale shall be allocated between the award credits and the other components of the sale. The consideration allocated to the award credits shall be measured by reference to their fair value. 
First, if the entity supplies the awards itself, it shall recognize the consideration allocated to award credits as revenue when award credits are redeemed and it fulfills its obligations to supply awards. The amount of revenue recognized shall be based on the number of award credits that have been redeemed in exchange for awards, relative to the total number expected to be redeemed.

Hence, on the initial sale, the fair value of the incentives is deferred being,

(Dr) Cash xx;

(Cr) Revenue xx;

Deferred revenue $x x$;

The entity will recognize revenue when credits are redeemed,

(Dr) Deferred revenue xx (Cr) Revenue xx.

If a third party supplies the awards, the entity shall assess whether it is collecting the consideration allocated to the award credits on its own account or on behalf of the third party.

\subsection{Customer Loyalty Programs Related Laws and Regulations}

For the case research, we examine the following related laws and regulations: Article 1, 6, 7, and 13 of Value-added tax act; Article 48 of its implementing ordinances

According to Article 1 (Taxable Objects), (1) Value-added taxes shall be imposed on the transactions falling under the following sub-paragraphs:

i. Supply of goods or services;

ii. Import of goods.

(2) The term "goods" in paragraph (1) means all tangible things and intangible things which have property value.

(3) The term "services" in paragraph (1) means all services and activities other than goods, which have property value.

Article 6 states "Supply of Goods". Where an entrepreneur directly uses or consumes for his/her own business the goods produced or acquired in connection with his/her own business, those as prescribed by Presidential Decree shall be considered as the supply of goods.

Article 7 states "Supply of Services". The supply of services shall be either the supply of services or having others use the goods, facilities or rights, pursuant to all contractual and legal grounds. Where an entrepreneur supplies services directly for his/her own business, it shall be considered to have supplied services to himself/herself, as prescribed by Presidential Decree. The supply of services to others without compensation or the supply of labor under an employment relationship shall not be considered as the supply of service.

Under Article 13, the tax base for value-added taxes on the supply of goods or services shall be the total amount of value under the following sub-paragraphs: Provided, that value-added taxes shall not be included therein:

i. Where payments are given in money: the payments;

ii. Where other payments than money are given: the current market price of goods or services supplied by the supplier himself/herself;

iii. Where payments for the supply of goods are unjustifiably low or no payments are made: the current market price of goods supplied by the supplier himself/herself;

However, amounts under the following sub-paragraphs shall not be included in the tax base:

i. The amount of discount;

ii. The value of returned goods;

iii. The value of goods which are damaged, broken, or lost before they reach the person receiving the supply;

iv. The bad debt and bounty on the value of supply after the goods or services are supplied, and other amounts similar to them.

In addition, the scope of unjustified compensation and discount is defined; the unjustified compensation is defined to be a lower compensation than the market price, which is recognized to unjustifiably reduce the tax burden as to the supply amount of goods and services for a transaction with the parties of special relationship. There are 2 types of discount. First type of discount is defined as an amount to directly exempt a certain amount from a conventional supply price at the time of supplying goods or services in accordance with the quality and 
quantity and also the payment or other supply conditions for shipment and supply price in terms of supplying goods or services (amended, Dec 31, 2001). the second type of discount is defined as the amount that discounts a certain amount when paying account receivables for the compensation of supply as to sales on credit or receiving money for account receivables for the compensation of supply before the contract expiration date (amended, Feb $28,2007)$.

\section{Case Study}

In this section we examine a case and give a conclusion for the case based on the related laws and regulations as well as reinterpretation of the Ministry of Strategy and Finance Case.

\subsection{Review on Taxation Problem under the Value Added Tax Law in Association with the Mileage System}

\subsubsection{Facts and Case Study}

"Company" operates subsidiary businesses (facilities) that are taxable in addition to a tax-exempted main business place. "Company" saves mileages equivalent to a certain amount of the used amount to customers who use the main business place and allows the relevant customers to pay for the compensation of the provided services by the earned points when they use subsidiary facilities. Thus, this case study is to examine whether the services provided by a company upon the payment by a customer's earned points are subject to the taxation of value added tax. The difference from the conventional mileages is the fact that it is possible to pay at the designated franchisees in a nearby region with the relevant points and also a company pays the paid amount. On that account, there may exist contracting arguments including an argument saying that it is subject to the taxation of value added tax and another argument saying that it is not subject to the taxation of value added tax. This paper will first examine as to each argument and reason and then discuss on the implications provided by the conclusion and cases.

\subsubsection{Argument for not Being Subject to the Taxation of Value Added Tax Taxation and Relevant Reasons}

The argument and reasons for not being subject to the taxation of value added tax as to the above facts and case study are as follows.

First, it is based on the definition of "supply of services" of Paragraph 3, Article 7 of the value added tax law. "Supplying services to others without receiving compensation or providing labor by employment relationship is not considered as a provision of services," Paragraph 3, Article 7 of the value added tax law states. There does not exist any compensation collected from customers and also any other compensation flowed in from outside when a company provides services through points. Whether to receive compensation should be judged by the company's point of view rather than the customer's point of view; therefore, point does not have any monetary value from the company's perspective. In addition, the substance of a transaction is not about a customer paying points to a company to compensate for services. Rather, it is a mere process of lapse for the points granted to a customer by a company. Thus, it can be concluded that providing services without receiving any compensation as indicated in this case study is not subject to the taxation of value added tax since it is a free or discount provision of services.

Second, Paragraph 1, Article 48 of the enforcement ordinance of the value added tax law states that the tax base as to goods or services should include all monetary values received from a transaction partner. However, point does not have monetary value to a company; thus, it cannot be a compensation for services and consequently it is not to be included in the tax base of value added tax. Mileage is a bonus or incentive to be provided for the purpose of inducing customers' next purchase; thus, it can hardly be regarded as money. Also, a supplier provides goods or services without receiving any monetary compensation from a customer owning mileage; thus, it should be regarded as free or discount provision.

Third, the objects to be included in the tax base as for the amount equivalent to mileage or points is limited to goods. In other words, there is no legal basis under the value added tax law as to the taxation for free services. The objects for including conventional mileage in the tax base of value added tax is limited to provision of goods under the value added tax law and services are excluded from the target for application. According to Article 48 of the enforcement ordinance of the value added tax law, the relevant amount equivalent to mileage should be included in the tax base when a business saves mileage equivalent to a certain ratio of sales revenue to a customer and the customer receives goods and pays for all or part of the compensation by the earned mileage (February 18, 2010, creation).

In conclusion, it is reasonable that such transaction is excluded from the tax base in tandem with the reinterpretation of the Ministry of Strategy and Finance Case No. 319 (March 29, 2006) and Paragraph 13, 
Article 48 of the enforcement ordinance of the value added tax law since it is a mileage transaction that does not have any monetary value.

\subsubsection{Argument for Being Subject to the Taxation of Value Added Tax and Relevant Reasons}

There exists the contracting opinion in addition to the argument for being subject to the taxation of value added tax. The relevant reasons are as follows.

First, the reason why the payment amount is included in the tax base when paying for the provision of goods by mileage is because the corresponding mileage is considered as a payment method that has a monetary value. Thus, it is reasonable to regard provision of services in the same context of goods since it is a provision that utilizes the payment method called mileage. Second, it is important to point out an issue of tax equality. It is not possible to levy tax on the value added taxable amount to those businesses who conduct tax exempted business and taxable business simultaneously even though they are subject to taxation since they create additional values under the value added tax by utilizing taxable sales revenue as a tool to appropriate tax exempted sales revenue through making use of mileage. And there may exist an issue of tax equality due to the simple difference of sales method even though the same additional values are created by providing the same services.

\subsection{Authoritative Interpretation Related to Mileage}

Since there does not exist any clear interpretation criterion as to the taxation of value added tax, it would be imperative to rely on the authoritative interpretation cases as to the cases related to mileage. The related authoritative interpretation cases are as follows.

When a business operating an Internet gaming site receives compensation for providing online gaming service to users, it is taxed for value added tax since it is equivalent to the provision of services in accordance with the provision of Paragraph 1, Article 7 of the value added tax law. However, when it provides online gaming service by the earned points without receiving compensation separately, it is not taxed for value added tax in accordance with the provision (free provision of services) of Paragraph 3, Article 7 of the value added tax law (Seosam-654, April 1, 2004)

When a business selling goods through online saves mileage equivalent to a certain ratio of sales revenue to a customer's account and the relevant customer pays for all or part of the purchased amount by the earned mileage when purchasing a good, the amount equivalent to the corresponding mileage is included in the tax base of value added tax. (Re-consumption-319, March 29, 2006)

Based on the review of authoritative interpretations, it would be possible to find out that those transactions taxed by value added tax are consistently limited to goods. From the existing authoritative interpretations and re-consumption-319 (March 29, 2006), the mileage taxation was limited to provision of goods and it was also clearly confirmed that provision of services was excluded. Moreover, it was interpreted that the provision of services that was paid by mileage from Seosam-654 (April 1, 2004) would not be taxed for value added tax taxation and there is not any interpretation for taxation on provision of services even after the interpretation of re-consumption-319 (April 29, 2006). Taxing only goods as excluding services is also confirmed in Paragraph 13, Article 48 of the enforcement ordinance of the valued added tax law; thus, it conforms to the position of the existing interpretation.

\subsection{Conclusion for Case Study}

The conclusion of the Ministry of Strategy and Finance based on the relevant laws and regulations and cases is that the amount equivalent to the corresponding mileage should not be included in the tax base of value added tax when paying by the earned points. In addition, it would be imperative to consider the following perspectives for case study as well as the relevant established rules.

First, appropriating in tax base when receiving goods or services by utilizing the earned mileage after a certain period of time is like ignoring the point that a provision of goods or services is implemented without actual payment for compensation from the supplier's perspective. Therefore, an issue related to double taxation might occur on this account. Second, when consumers receive goods (including cyber goods) by utilizing mileage, it is included in the tax base even for the case where the mileage is included in the tax base. On the other hand, it is not included in the tax base when receiving services. Thus, it would be imperative to pay attention to the point that there occur some cases that would process the same mileage in a different way. 


\subsection{Problems on Taxation of Value Added Tax for Transactions}

\subsubsection{Double Taxation Problem and Taxation Equality Problem}

As stated previously, it would be first imperative to consider the problems related to double taxation. Appropriating in tax base when receiving goods or services by utilizing the earned mileage after a certain period of time may cause the problems related to double taxation. In addition, when consumers receive goods (including cyber goods) by utilizing mileage, it is included in the tax base even for the case where the mileage is included in the tax base. On the other hand, it is not included in the tax base when receiving services. Thus, the cases of processing the equivalent mileage in a different way occur and they may also cause the taxation equality problem. The equality for tax burden between two taxpayers who selected different sales methods may be distorted as argued by Chang (2011).

\subsubsection{Impact on Industries Operating Mileage System}

When value added tax is levied on a transaction, there might occur a huge impact on the other industries such as the airline industry. In the case of airline that is the most important case to operate the mileage system, value added tax is not being paid when paying for bonus air fares by utilizing mileage since this is considered as free provision of service. In this case, there are such problems as considering the payment with mileage instead of cash for receiving services as free provision of service and the relevant mileage not being taxed at any phase for receiving tax exempted goods. However, if levying tax by considering these cases uniformly as subsidy, etc., then it will first contradict with the major premise of not levying tax on free provision of service (difficulty for evaluation) and second there may occur such problem as levying value added tax to customers separately or paying with allowance fund despite providing air transport service.

In addition, free provision of service through mileage is being utilized as a common competition tool across almost all the industries including large conglomerates such as oil refiners and mobile carriers and small businesses such as hair shop, laundry shop, etc. Therefore, it is expected that the impact of levying value added tax on a transaction be huge as also influencing the other industries as evidenced in the case.

\subsubsection{Taxation Issue for Similar Free Services}

Meanwhile, value added tax may be levied on provision of post-free service that is similar to mileage, and this can expand the impact throughout the industry. As for the similar cases as the mileage system, the manufacturing industry, the software development industry, the construction industry, etc. provide services for free by granting a right (repair, guidance, education, performance improvement, etc.) to customers to get support for manufactured goods as a result of the sales of manufactured goods. This is actually equivalent to the right and duty relationship and the economic substance in terms of granting a right (free use of service) to customers and making them fulfill the subsequent duties with the exception of the formal aspect that is not to be managed by the quantified numbers as compared with the mileage system.

Therefore, it is expected that levying value added tax on a transaction will expand the impact not only on the industries that operate the mileage system but also the similar free service transactions.

\section{Conclusion}

This study examines the appropriateness of taxation on customer loyalty programs by referring a company which operates both taxable subsidiary businesses in addition to tax-exempt main business. "Company" saves mileages equivalent to a certain amount of the used amount to customers who use the main business place and allows the relevant customers to pay for the compensation of the provided services by the earned points when they use subsidiary facilities.

There is a controversy about whether the services provided by a company upon the payment by a customer's earned points are liable to value added tax, however we conclude that the amount equivalent to the corresponding mileage are not liable for taxation when paying by the earned points. The conclusion is based on the definition of "supply of services" in accordance with Paragraph 3, Article 7 of the value added tax law, "Supplying services to others without receiving compensation or providing labor by employment relationship is not considered as a provision of services". In addition, based on the review of authoritative interpretations, the transactions subject to value added tax are limited to goods. There may be the contracting opinion when we regard corresponding mileage as a payment method. Also, we should not overlook tax equality issue.

However, as stated in the introductory part, the change of accounting rule for mileage with the adoption of K-IFRS could have a material impact on the industry offering loyalty programs to its customers. In the current situation, it is required to establish the mileage related value added tax laws and regulations. 
As this paper is based on a case in business practice, there are some limitations including lack of research method, nonetheless, the analysis indicates some important policy implications. This case study only establishes that firms which have greater opportunities for future research about value added tax laws and regulations.

\section{References}

Dowling, G. R., \& Uncles, M. (1997). Do customer loyalty programs really work? Sloan Management Review, $38(4), 71-82$.

Government. (2006). The reinterpretation of the Ministry of Strategy and Finance Case No. 319. March 29, 2006; Seosam-654, April 1, 2004.

Jang, K. Y. (2011). The problems and improvement plans of the taxation on mileage in VAT (Value Added Tax) Law. Accounting Research, 16(1), 259-283.

Korean Accounting Standards Board. (2013). Korean International Financial Reporting Standards 2113: Customer Loyalty Programs. Retrieved from http://www.kasb.or.kr/

Lee, H. I., Hyuk, S., \& Park, S. J. (2010). Effect of the IFRS on mileage programs. Accounting Journal, 19(2), 483-504.

Ministry of Government Legislation. (2009). Korean Laws and Policies. Tribunal Case No. 2342. Retrieved from http://www.moleg.go.kr/Tax

\section{Copyrights}

Copyright for this article is retained by the author(s), with first publication rights granted to the journal.

This is an open-access article distributed under the terms and conditions of the Creative Commons Attribution license (http://creativecommons.org/licenses/by/3.0/). 